Article

\title{
The Third Wave of COVID-19 versus the Residential Preferences in Poland: An Assessment of Economic Factors and Psychological Determinants
}

\author{
Anna Stankowska ${ }^{1}$ (D) and Izabela Stankowska-Mazur ${ }^{2, *(D)}$ \\ 1 Department of Innovative City, Collegium of Business Administration, SGH Warsaw School of Economics, \\ 02-554 Warsaw, Poland; astanko@sgh.waw.pl \\ 2 Department of Psychology and Cognitive Science, Adam Mickiewicz University, 61-712 Poznań, Poland \\ * Correspondence: izastan@amu.edu.pl
}

check for

updates

Citation: Stankowska, A.;

Stankowska-Mazur, I. The Third

Wave of COVID-19 versus the

Residential Preferences in Poland: An

Assessment of Economic Factors and

Psychological Determinants.

Sustainability 2022, 14, 1339. https://

doi.org/10.3390/su14031339

Academic Editors: Tomasz Rokicki,

Sebastian Saniuk, Dariusz Milewski

and Lester Johnson

Received: 30 November 2021

Accepted: 12 January 2022

Published: 25 January 2022

Publisher's Note: MDPI stays neutral with regard to jurisdictional claims in published maps and institutional affiliations.

Copyright: (C) 2022 by the authors. Licensee MDPI, Basel, Switzerland. This article is an open access article distributed under the terms and conditions of the Creative Commons Attribution (CC BY) license (https:// creativecommons.org/licenses/by/ $4.0 /)$.

\begin{abstract}
The COVID-19 pandemic triggered a reflection on our need for contact with nature. It was the result of suddenly imposed limitations of the everyday functioning of many people and confining them to the space of their own house or apartment. This paper presents the results of a study on the preferences of Polish city dwellers in terms of their need for contact with nature at their place of residence before the COVID-19 outbreak and after the third wave of the COVID-19 pandemic. The purpose of the study was to identify any relationship between preferences regarding access to nature at the place of residence prior to and during the third wave of the COVID-19 pandemic and variables such as gender, age, background, and distance between the place of residence and any natural or urban green spaces. An online survey was used to examine urban residents' need for access to nature. Significant gender differences in preferences, both prior to and during the pandemic, were found. Preferences also varied depending on the distance between the place of residence and natural and urban green spaces and depending on the origin of the interviewee (urban or rural). The origin was found to have a significant impact on preferences. The need for contact with nature at the place of residence, both before and after the pandemic, was found to be greater among respondents from rural areas.
\end{abstract}

Keywords: COVID-19; residential preferences; need for contact with nature; natural and urban green spaces

\section{Introduction}

The ongoing COVID-19 pandemic has triggered a number of social and economic changes [1]. It has forced us to suddenly adapt to new situations and challenges in our daily functioning, at both individual and societal levels. Urban residents are thought to have experienced these changes in a particular way due to the restrictions on movement that have confined them to their homes for weeks at a time, while also significantly hindering their contact with nature. Domestic spaces, which for many had been places of refuge and relaxation, have gained additional functions. Following the introduction of remote working and learning, the closing of public buildings, and restrictions on the use of green spaces, much more time was spent indoors. Not surprisingly, several significant and lasting changes to the way we use our homes have been observed.

The simultaneous use of houses/apartments by all household members (workers, pre-school and school children, pensioners, etc.) may generate atypical behavior and affect housing preferences. These preferences, in turn, may result in a change of behavior in terms of the selection of apartments/houses and, consequently, have an impact on the residential real estate market. Unquestionably, the residential market in many developed countries is saturated (e.g., Great Britain, Germany), and, consequently, it cannot be easily adjusted to the changing preferences of inhabitants. The mismatch between demand and supply may 
lead, among other things, to rapid changes in housing prices [2], which is an undesirable phenomenon that affects the housing situation of a country. It is, admittedly, still too early to draw any definite conclusions about permanent changes and how much the preferences of the Polish society and the real estate market in Poland have changed as a result of the lockdown. However, research on the impact of COVID-19, in its various aspects, provides an increasingly accurate understanding of the issue; a number of revealing trends have been identified (Project conducted in 2020-2021, title: Transgressive and protection human behavior and housing preferences in the context of experiencing a COVID-19 pandemic, conducted at the Department of Psychology and Cognitive Science Adam Mickiewicz University Poznań and SGH Warsaw School of Economics.). Interesting from the point of view of the analyzed issue are, inter alia, studies on the role of the city and urbanity in initiating social change processes [3], the experience of the pandemic (study conducted under the direction of A. Karwacki [4]), the socio-economic situation of women and men in Poland during the pandemic [5,6], impact on the economy and employment market [7], changing attitudes towards COVID-19 [8] etc.

However, an analysis of the situation during the pandemic has revealed a significant decline in rental demand. Many tenants decided to move out of their accommodation and return to their family homes. Interest in houses and larger apartments for sale has also increased significantly [9]. Economic (consumer attitudes), social, and psychological factors have played an important role in this.

Literature and econometric studies indicate how factors such as the location, the surface of the house or apartment, the number of rooms, the price, etc. [10-12] influence the demand for housing. This is consistent with the economic theory according to which households make decisions in a world of limited resources. This means compromises and choices regarding, inter alia, spending on housing and on other goods. Additional factors affecting decisions include prices, interest rates, taxes, and dividends as well as broadly defined traditions, habits, and tastes. These are called individual consumer preferences.

Housing preferences are also explained by other macro-level motivational factors. They are determinants of the stated housing preferences [13]. In his model, J.K. Brueckner [14] assumes that the only significant factor in choosing a place to live is the commute to the city center. On the other hand, P.M. Schirmer et al. [15] point to factors such as housing density, access to green areas, education, goods and services, the income of the household, etc. A. Li., I. Ossokina, and T. Arentze [16] present an empirical estimation of household owners' preferences for greenery and an overview of land use in the Netherlands. Based on their findings, a model was devised for municipalities and developers to optimize urban housing development, taking into account financial, climate, and social objectives (matching housing demand and supply).

However, human preferences can change when activities usually performed outside are relocated to home offices [17-19], which happened during the COVID-19 pandemic. An extensive literature presenting recent reports from pandemic research emphasizes a number of factors that may be associated with housing preferences, both in economic and psychological terms [20-38]. Restrictions and limitations imposed by individual countries to limit the spread of COVID-19 (e.g., Switzerland [39]; Iran [40]) resulted in people being confined to their homes. This situation may cause greater health concerns, as not having an adequate space in which to work, study, exercise, and have some privacy may generate higher levels of stress and, ultimately, affect the well-being of residents [38,41-44]. A. Nanda et al. [45] studied potential changes in housing preferences in the UK due to the COVID-19 pandemic, indicating, among others, spatial inequalities contingent on socioeconomic and demographic conditions (income, access to work, ethnicity, age, migration status). A. Pagani et al. [46] studied the impact of the first wave of COVID-19 on housing preferences in Switzerland, in particular the extent to which functions assigned to houses changed during the pandemic. They were related to socio-demographic characteristics, changes in leisure activities, and to the environmental conditions of respondents. Two profiles of residents were identified depending on how they responded to the stress related to changes 
in the functioning of their houses. In another study conducted in Tehran, Z. Mahsa, Y. Seyed-Abbas, and H. Seyed-Bagher [40] explored relationships between physical health, mental health, and socioeconomic lifestyle changes affecting the interior architecture of houses. Factors such as access to natural light, view from the window, acoustics, and open or semi-open spaces strongly affect our mental health. A study carried out in Italy during the COVID-19 pandemic [47] examined the needs and preferences of residents, indicating changes in housing preferences. Researchers came to similar conclusions when studying the Spanish market [48]; they also demonstrated that the COVID-19 pandemic led to a shift in housing preferences. Certain physical characteristics of housing, such as the availability of outdoor spaces or the surface are now sought-after; the popularity of single-family homes has also increased.

Already before the pandemic, the growing awareness of the impact of one's immediate environment on physical and mental health had resulted in a growing interest in the functional aspects of architectural and urban design before the pandemic. Nowadays, architectural design taking into account social design or participative design has become a standard in highly developed countries. It refers to personal preferences of future users regarding the use of the designed spaces [49]. An important element of it is the relationship between humans and nature, including green areas. This can be partly explained by the fact that we no longer treat nature solely in utilitarian terms, as a source of raw materials used as commodities; it is no longer seen solely as an object of exploitation but rather as a partner in all of its forms [50].

A. Abraham, K. Sommerhalder, H. Bolliger-Salzmann, and T. Abel [51] performed a thorough meta-analysis of the available research results regarding the influence of natural surroundings on our physical and mental health. On the basis of a literature review, they found a conceptual correlation between human well-being and six components: ecological, aesthetic, physical, psychological, social, and educational. With regard to these components, researchers found as follows:

1. ecological component-contact with nature has a positive effect on human health; certain landscape elements, such as noise, sounds, and weather, affect our health;

2. aesthetic component-pro-health urban design is an important determinant of human health;

3. physical component-natural environment affects our physical activity; landscaped areas designed and perceived to be conducive to physical activity have a bearing on actual levels of physical activity;

4. psychological component-natural environment determines how we cope with stress and mental fatigue, affects our psychological well-being, and has an impact on the incidence of mental disorders;

5. social component-the proximity of green spaces increases our social engagement with the environment and enhances the sense of social integration;

6. educational component-green urban landscapes and rural landscapes have a positive impact on the motor, cognitive, emotional, and social development of children and adolescents.

Contact with nature can take various forms. Activities such as walks in the forest, picking mushrooms, mountain hikes, and outdoor sports are the most engaging and stimulate several senses. However, equally important is passive contact with nature: observing wildlife, imagining it while reading or experiencing it while watching a film or looking at photographs, spending time in the wilderness or in urban green spaces. This is because humans react strongly to nature and its processes, regardless of the number of channels through which they perceive it [52]. J. Mass et al. [53] examined, for example, the effect of the distance between the place of residence and green areas on the prevalence of certain diseases. They found a higher prevalence of 15 out of 24 diseases identified in the analysis among Dutch patients living more than $1 \mathrm{~km}$ away from green areas. This relationship was strongest in the case of mental disorders, such as depression and anxiety. Proximity to green spaces was also shown to be particularly important for children and 
adults with a lower socioeconomic status. In both groups, a significantly lower incidence of mental disorders was observed among those who had more green areas within $1 \mathrm{~km}$ of their place of residence. C. Song et al. [54] examined how city residents are affected by walks through urban parks and through built areas within the city. The research proved that walking in the park in the spring boosts the parasympathetic nervous system (its activity increases in situations of rest and relaxation), inhibits the activity of the sympathetic nervous system (responsible for mobilizing the body, e.g., in situations of stress), and reduces the heart rate. They confirmed that this effect is observed regardless of the season (the experiment was repeated in autumn and winter) and that physical activities within green spaces have relaxing effects. On the other hand, J.M. Cackowski and J. Nasar [55] enquired into the impact of natural surroundings on levels of frustration and aggression. They concluded that access to urban greenery, such as parks and other types of vegetation, increases frustration tolerance.

These considerations gave rise to interdisciplinary research based on the findings of psychology and economics. The aim of the study was to identify preferences regarding contact with nature in the place of residence among the inhabitants of cities with a population of over 50,000 and with a number of socioeconomic factors. Preferences were assessed retrospectively (prior to the COVID-19 pandemic) and at the time of the study (following the third wave of the pandemic).

The underlying research hypothesis was that a prolonged pandemic experience would contribute to a change in preferences regarding contact with nature within one's city of residence.

These considerations led to the formulation of the research hypothesis that the longterm experience of the pandemic will contribute to a change in preferences regarding contact with nature within the place of residence. It was expected that Polish city dwellers would feel a greater need for contact with nature compared to the situation prior to the pandemic, mostly as a result of reflection on the relationship between humans and nature, of which the former form an integral part. This relationship is one of the fundamental values of human life. Potential impacts of an authentic contact with nature are manifold. This relationship determines the emotions of individuals and the way they spend their time, defines the lifestyle, and has a positive effect on physical and mental health and on one's general functioning at all levels [56].

\section{Materials and Methods}

\subsection{Recruitment of Participants and Study Procedure}

The presented analysis of results forms part of a larger project (Project conducted in 2020-2021, title: Transgressive and protection human behavior and housing preferences in the context of experiencing a COVID-19 pandemic, conducted at the Department of Psychology and Cognitive Science Adam Mickiewicz University Poznań and SGH Warsaw School of Economics) initiated following the first wave of the pandemic in Poland (from September 2020 onwards). The empirical material used in this paper was collected between April 2021 and September 2021 with a view to describing the preferences of Polish city dwellers after the third wave of the pandemic. It was assumed that the preferences of people at this stage of the pandemic may be different from those observed at its earlier stages.

An online survey questionnaire was used. The invitation to participate in the study was posted on social media and on university websites. We also relied on the snowball method [57,58], i.e., non-random sampling involving the recruitment of participants by other participants, in an attempt to quickly increase the size of the survey sample. It also allowed us to reach respondents in the absence of a census. The criteria for inclusion in the study sample were the age (over 18) and residence (a Polish city with a population of over $50,000)$ of the respondents.

Among 524 respondents living in cities with more than 50,000 residents, 233 completed questionnaires were used for further analysis. The aim was to capture the specificity of 
preferences revealed following the third wave of the pandemic and before the beginning of the fourth wave was announced in Poland, and, therefore, it was decided to end the collection of questionnaires and to analyze the obtained responses. However, conclusions drawn from the sample may not be representative of the entire country.

\subsection{Study Participants}

The research group (Table 1) included 233 residents of cities with a population of more than $50,000(52.40 \%$ of them were men), aged $25-56(\mathrm{M}=34, \mathrm{SD}=7.9)$. The majority of the respondents come from urban areas $(68.20 \%)$ and earn a monthly income of more than PLN 3501. The largest group of respondents live more than $1.1 \mathrm{~km}$ away from an area of natural greenery, e.g., a meadow or forest (59.23\%), and at a distance from 0.51 to $1.0 \mathrm{~km}$ from urban green areas, such as parks or city gardens $(63.95 \%)$. Less than $17 \%$ of the respondents have their own garden next to their house or apartment. Everyday behavior of respondents indicates that they care for animals and plants (44.21\%). They keep pets and plants, which have been domesticated by humans and are, therefore, strongly dependent on them. They are least likely to care for all nature (6.44\%), including geological features and natural phenomena. A fairly large group consists of people who care for a particular animal or plant species, while lacking or showing limited sensitivity in relation to other species $(31.33 \%)$.

Table 1. Selected socioeconomic characteristics of the sample $(N=233)$.

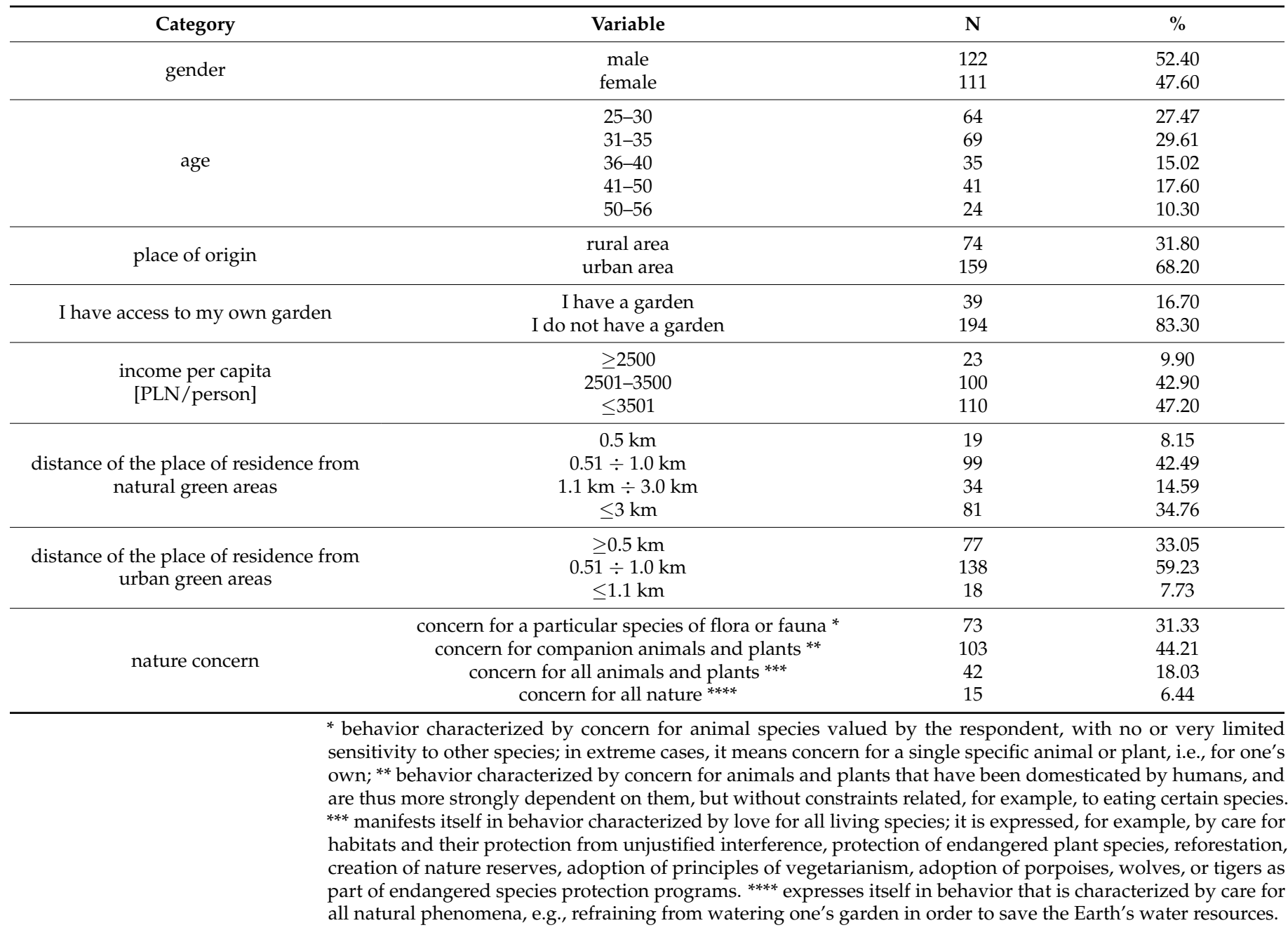




\subsection{Research Tools}

To measure the variables included in the presented part of the study, a questionnaire investigating the respondents' preferences regarding contact with nature in the place of residence and a socio-demographic metric were used.

Preferences regarding contact with nature in the place of residence were estimated using closed-ended questions. These concerned the assessment of the need for contact with nature at the place of residence in the pre-pandemic period and on the day of the survey. Preferences in the pre-pandemic period were assessed retrospectively. In the first part, respondents were asked about the importance of living in a place that allows contact with nature to varying degrees (proximity to natural green areas, proximity to urban green areas, own garden at home, own land outside the place of residence, access to a private outdoor space such as a balcony or a terrace, a green view outside the window) before the pandemic. Participants responded to this on a 3-point scale (1-"not important/not very important", 2-“don't know/no opinion", 3-“important/very important"). In the second part, respondents were asked to state their preferences at the time of the survey, i.e., following the third wave of the pandemic.

Gender, age, place of origin, income, and access to a private garden as well as the distance from the current place of residence to natural and urban green areas were determined using questions included in the metric section. In order to fully describe the group of respondents, the latter were asked to assess their concern for nature by indicating which statement most accurately described their beliefs and attitudes, as manifested in their actions taken towards nature ("Which statement best describes the daily actions you take?"). Respondents responded to statements categorized as concern for a particular species of flora and fauna, concern for companion animals and plants, concern for all animals and plants, and concern for all nature (including, for instance, geological features).

\subsection{Data Analysis}

In order to answer research questions:

1. Is there a relationship between one's preferences regarding contact with nature in the place of residence before the first wave of the COVID-19 pandemic and one's gender, age, background (rural or urban), and the distance of the place of residence from natural and urban green spaces?

2. Is there is a correlation between preferences regarding contact with nature in the place of residence after the third wave of the COVID-19 pandemic and one's gender, age, background (rural or urban), and the distance of the place of residence from natural and urban green spaces?

Statistical analyses were performed using the IBM SPSS Statistics 27 package, which was applied in order to perform an analysis of basic descriptive statistical data, exploratory PCA with a reliability test, Student's $t$ test, Mann-Whitney U test, Pearson's r correlation analysis, and variance analysis. The significance level was evaluated at $\alpha=0.05$.

\section{Results}

Obtained results (Table 2) indicate that, when it comes to preferences regarding contact with nature in the place of residence prior to the pandemic, having one's own plot of land outside the place of residence (54.08\%) and the proximity to natural green areas $(27.47 \%)$ were considered most important by the respondents. At the same time, for as many as $60.94 \%$ of them, proximity to natural green areas was considered of limited or no value. Conversely, having a balcony or a terrace $(81.97 \%$ ) and having a private garden by the house $(63.09 \%)$ were considered least important. 
Table 2. Preferences regarding contact with nature before and during the pandemic.

\begin{tabular}{|c|c|c|c|c|c|}
\hline \multirow{2}{*}{$\begin{array}{l}\text { Preferences } \\
\text { Regarding }\end{array}$} & \multirow{2}{*}{ Value } & \multicolumn{2}{|c|}{ Before the COVID-19 Pandemic } & \multicolumn{2}{|c|}{ During the COVID-19 Pandemic } \\
\hline & & Quantity & $\mathbf{N} \%$ & Quantity & $\mathbf{N} \%$ \\
\hline \multirow{3}{*}{$\begin{array}{l}\text { Proximity to natural } \\
\text { green areas }\end{array}$} & not important/not very important & 142 & $60.94 \%$ & 9 & $3.86 \%$ \\
\hline & I have no opinion & 27 & $11.59 \%$ & 33 & $14.16 \%$ \\
\hline & important/very important & 64 & $27.47 \%$ & 191 & $81.97 \%$ \\
\hline \multirow{3}{*}{$\begin{array}{l}\text { Proximity to urban } \\
\text { green areas }\end{array}$} & not important/not very important & 9 & $3.86 \%$ & 2 & $0.86 \%$ \\
\hline & I have no opinion & 198 & $84.98 \%$ & 101 & $43.35 \%$ \\
\hline & important/very important & 26 & $11.16 \%$ & 130 & $55.79 \%$ \\
\hline \multirow{2}{*}{$\begin{array}{l}\text { Possession of a } \\
\text { balcony/terrace }\end{array}$} & not important/not very important & 42 & $18.03 \%$ & 29 & $12.45 \%$ \\
\hline & important/very important & 191 & $81.97 \%$ & 204 & $87.55 \%$ \\
\hline \multirow{3}{*}{$\begin{array}{l}\text { Green view outside } \\
\text { the window }\end{array}$} & not important/not very important & 53 & $22.75 \%$ & 3 & $1.29 \%$ \\
\hline & I have no opinion & 134 & $57.51 \%$ & 133 & $57.08 \%$ \\
\hline & important/very important & 46 & $19.74 \%$ & 97 & $41.63 \%$ \\
\hline \multirow{2}{*}{$\begin{array}{l}\text { Own land outside the } \\
\text { place of residence }\end{array}$} & not important/not very important & 126 & $54.08 \%$ & 97 & $41.63 \%$ \\
\hline & important/very important & 107 & $45.92 \%$ & 136 & $58.37 \%$ \\
\hline \multirow{3}{*}{ Having a garden } & not important/not very important & 147 & $63.09 \%$ & 124 & $53.22 \%$ \\
\hline & I have no opinion & 65 & $27.90 \%$ & 26 & $11.16 \%$ \\
\hline & important/very important & 21 & $9.01 \%$ & 83 & $35.62 \%$ \\
\hline
\end{tabular}

At the time of the survey, respondents indicated proximity to natural green areas $(81.97 \%)$ and urban green areas $(55.79 \%)$ as the most important. Having a balcony or a terrace $(87.55 \%)$ and having one's own plot of land outside one's area of residence $(58.37 \%)$ remained least important.

Prior to the pandemic, respondents most often had no opinion about their need for living close to urban green areas $(84.98 \%)$ and having a green view outside the window $(57.51 \%)$. During the pandemic, the number of people who had no opinion about the first element decreased almost by half, while the opinion about the second element practically did not change.

The analysis of answers provided by the respondents shows changes in terms of preferences regarding contact with nature in their place of residence prior to and during the pandemic. The greatest difference was observed in the preference for proximity to natural green areas. Before the pandemic, $60.94 \%$ of respondents considered it to be of little or no value, while for $27.47 \%$ it was important or very important. The experience of the pandemic resulted in a clear change. Proximity to natural green areas was unimportant to only $3.86 \%$ of the respondents; the number of respondents who considered it important increased to $81.97 \%$. Preferences changed considerably in terms of the proximity to urban green areas among those who considered it important or very important and among those having no opinion on the subject. As many as $84.98 \%$ of the respondents indicated that they had no opinion about it before the pandemic, while during the pandemic this figure dropped to $43.35 \%$. Similarly, before the pandemic, $11.16 \%$ of respondents considered proximity to urban green spaces as having little or no value. During the pandemic, 55.7\% of respondents declared it important. The change was least visible in the assessment of the value of having an apartment with a balcony or a terrace. The percentage of people considering a balcony or a terrace as important decreased from $18.03 \%$ to $12.45 \%$, and the percentage of those considering it unimportant increased from $81.97 \%$ to $87.55 \%$.

Factor analysis using the principal components method along with the Varimax rotation was carried out to create indicators of preferences regarding contact with nature close to home. Variables were created with respect to preferences prior to and during the pandemic. The settlement graph for the factor preference regarding contact with nature in the place of residence before the pandemic is shown in Figure 1, while during the pandemic, in Figure 2. The matrix of the rotated components, along with the level of reliability according to Cronbach's alpha method of individual factors, is shown in Table 3 (preferences before the pandemic) and in Table 4 (preferences following the end of the third wave). 


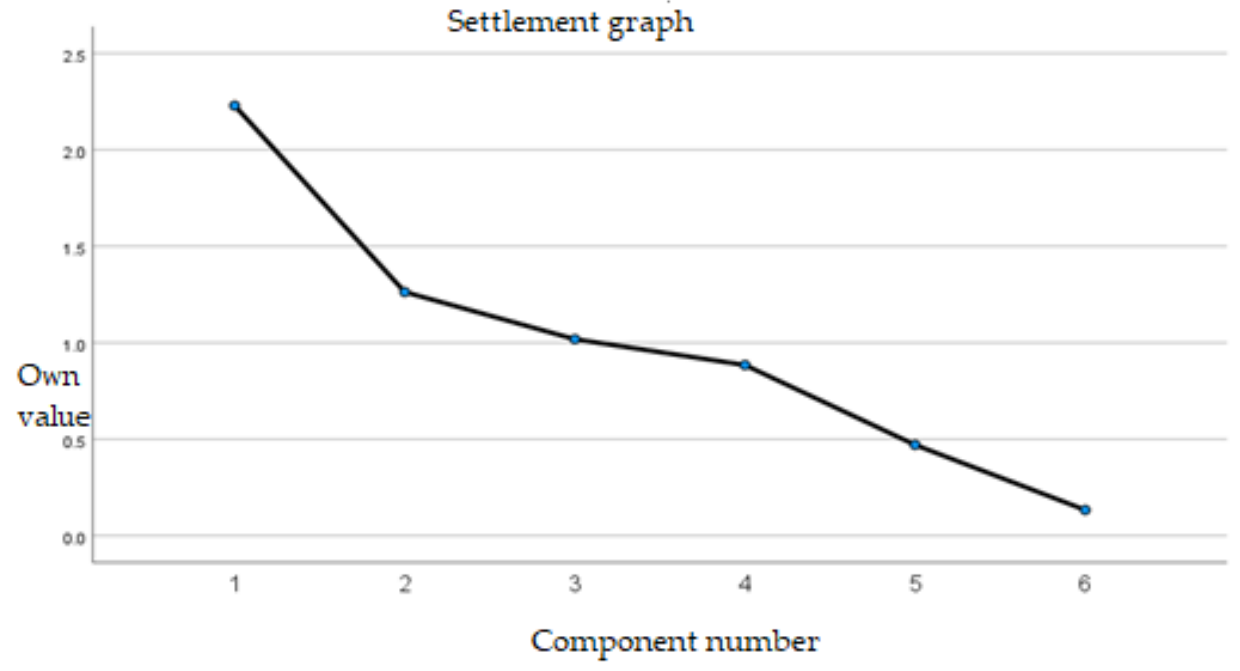

Figure 1. Settlement graph for the factor preference regarding contact with nature in the proximity of the place of residence before the pandemic.

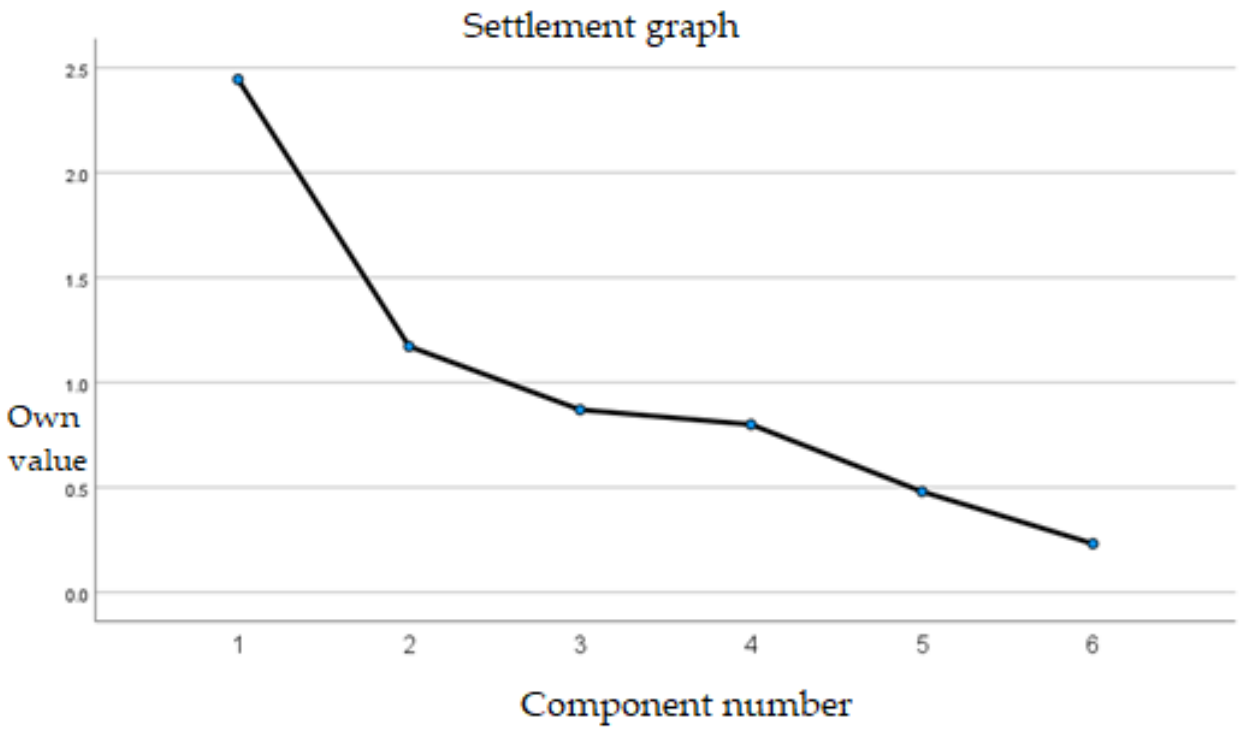

Figure 2. Settlement graph for the factor preference regarding contact with nature in the proximity of the place of residence during the pandemic.

As for the pre-pandemic preferences, three factors are extracted based on the analysis of the rotated component matrix and the scatter plot. Factor B does not enter into any scale, and factor $C$ does not meet sufficient reliability values. Therefore, only factor $A$, which meets reliability assumptions, was used for further analysis.

As for preferences declared after the third wave of the pandemic, two factors were extracted based on the analysis of the rotated component matrix and the scatter plot. Among them, green view outside the window entered the first scale (factor $A^{\prime}$ ). Factor $C^{\prime}$ does not fulfil reliability values. Therefore, only factor $\mathrm{A}^{\prime}$, which meets reliability assumptions, was used for further analyses.

The analysis of results obtained after extracting factor A and factor $\mathrm{A}^{\prime}$ revealed significant gender differences in preferences regarding contact with nature both before and during the pandemic. The strength of the effect is moderate (Table 5). 
Table 3. Rotated component matrix with the reliability level of each factor for the variable preference regarding contact with nature in the place of residence before the pandemic.

\begin{tabular}{|c|c|c|c|c|c|c|c|c|c|}
\hline \multirow{2}{*}{ Variable } & \multicolumn{3}{|c|}{ Factor 'A' } & \multicolumn{3}{|c|}{ Factor 'B' } & \multicolumn{3}{|c|}{ Factor ' $C^{\prime}$} \\
\hline & Loading & $\%$ & $\alpha$ & Loading & $\%$ & $\alpha$ & Loading & $\%$ & $\alpha$ \\
\hline having a garden & 0.92 & & & & & & & & \\
\hline proximity to natural green areas & 0.80 & 37.15 & 0.77 & & & & & & \\
\hline having a balcony/terrace & 0.77 & & & & & & & & \\
\hline green view outside the window & & & & 0.90 & 21.05 & - & & & \\
\hline own land outside the place of residence & & & & & & & 0.87 & & \\
\hline proximity to urban green areas & & & & & & & 0.53 & 16.98 & 0.09 \\
\hline
\end{tabular}

Table 4. The matrix of rotated components along with the reliability level of each factor for the variable preference regarding contact with nature during the pandemic.

\begin{tabular}{|c|c|c|c|c|c|c|}
\hline \multirow{2}{*}{ Variable } & \multicolumn{3}{|c|}{ Factor 'A' } & \multicolumn{3}{|c|}{ Factor ' $C^{\prime}$} \\
\hline & Loading & $\%$ & $\alpha$ & Loading & $\%$ & $\alpha$ \\
\hline having a garden & 0.86 & & & & & \\
\hline proximity to natural green areas & 0.84 & & & & & \\
\hline having a balcony/terrace & 0.80 & 40.75 & 0.77 & & & \\
\hline green view outside your window & 0.57 & & & & & \\
\hline own land outside the place of residence & & & & 0.73 & & \\
\hline proximity to urban green areas & & & & 0.72 & 19.53 & 0.24 \\
\hline
\end{tabular}

Table 5. Gender differences in preference regarding contact with nature before and during the pandemic.

\begin{tabular}{|c|c|c|c|c|c|c|c|c|c|}
\hline \multirow{2}{*}{ Variable } & \multicolumn{2}{|c|}{ Female $(n=122)$} & \multicolumn{2}{|c|}{ Male $(n=111)$} & \multicolumn{5}{|c|}{$95 \%$ CI } \\
\hline & $\mathbf{M}$ & SD & $\mathbf{M}$ & SD & $\mathbf{t}$ & $p$ & LL & UL & d Cohena \\
\hline $\begin{array}{l}\text { preference regarding contact with nature } \\
\text { before the pandemic }\end{array}$ & 4.61 & 1.74 & 3.97 & 1.52 & 2.97 & 0.003 & 0.21 & 1.05 & 0.39 \\
\hline $\begin{array}{c}\text { preference regarding contact with nature } \\
\text { during the pandemic }\end{array}$ & 8.91 & 2.10 & 8.14 & 2.09 & 2.81 & 0.005 & 0.23 & 1.32 & 0.37 \\
\hline
\end{tabular}

It showed no statistically significant association between age and preference, meaning that the age of respondents is not related to their preference regarding contact with nature either before $(\mathrm{r}=-0.07 ; p=0.265)$ or during $(\mathrm{r}=-0.11 ; p=0.097)$ the pandemic.

We also tested whether there were differences between individuals from urban and rural areas and their stated preferences regarding contact with nature both before and during the pandemic (Table 6). Here, too, significant differences were shown between people of different backgrounds in terms of the two examined variables. This effect is strong.

Table 6. Differences in origin (rural or urban) and preference regarding contact with nature before and during the pandemic.

\begin{tabular}{|c|c|c|c|c|c|c|c|c|c|c|c|}
\hline \multirow[b]{2}{*}{ Variable } & \multicolumn{4}{|c|}{ Rural $(n=74)$} & \multicolumn{4}{|c|}{ Urban $(n=159)$} & \multirow[b]{2}{*}{$\mathbf{Z}$} & \multirow[b]{2}{*}{$p$} & \multirow[b]{2}{*}{$\eta^{2}$} \\
\hline & $\begin{array}{l}\text { Average } \\
\text { Rank }\end{array}$ & $\mathbf{M}$ & $\mathrm{Me}$ & Min & $\begin{array}{c}\text { Average } \\
\text { Rank }\end{array}$ & $\mathbf{M}$ & Me & Min & & & \\
\hline $\begin{array}{l}\text { preference regarding contact with } \\
\text { nature before the pandemic }\end{array}$ & 195.94 & 6.51 & 6.00 & 5.00 & 80.26 & 3.28 & 3.00 & 3.00 & -13.25 & $<0.001$ & 0.76 \\
\hline $\begin{array}{l}\text { preference regarding contact with } \\
\text { nature during the pandemic }\end{array}$ & 194.12 & 11.24 & 12.00 & 9.00 & 81.11 & 7.28 & 7.00 & 5.00 & -12.32 & $<0.001$ & 0.65 \\
\hline
\end{tabular}

Given the results presented, it was examined whether one's gender and place of origin have an impact on the level of preference regarding contact with nature prior to and during 
the pandemic. For this purpose, MANOVA was applied in the $2 \times 2$ design. Detailed results are presented in Tables 7 and 8.

Table 7. Descriptive statistics across conditions for preferences regarding contact with nature before and during the pandemic.

\begin{tabular}{cccccc}
\hline \multirow{2}{*}{ Gender } & \multirow{2}{*}{ Background } & \multicolumn{2}{c}{$\begin{array}{c}\text { Before the COVID-19 } \\
\text { Pandemic }\end{array}$} & \multicolumn{2}{c}{$\begin{array}{c}\text { During the COVID-19 } \\
\text { Pandemic }\end{array}$} \\
\cline { 3 - 6 } & & $\mathbf{M}$ & SD & M & SD \\
\cline { 3 - 6 } Female & rural & 11.13 & 1.20 & 6.54 & 0.94 \\
& urban & 7.47 & 1.05 & 3.35 & 0.61 \\
\hline \multirow{2}{*}{ Male } & rural & 11.46 & 1.14 & 6.46 & 0.95 \\
& urban & 7.28 & 1.02 & 3.21 & 0.49 \\
\hline
\end{tabular}

Table 8. Relations between gender and place of origin and the need for contact with nature before and during the pandemic.

\begin{tabular}{clccccc}
\hline \multirow{2}{*}{ Effect } & $\begin{array}{c}\text { Preference Regarding } \\
\text { Contact with Nature }\end{array}$ & $\begin{array}{c}\text { Mean } \\
\text { Square }\end{array}$ & $\boldsymbol{d f}$ & $\boldsymbol{F}$ & $\boldsymbol{p}$ & eta \\
\hline \multirow{2}{*}{ Fixed } & before the pandemic & 266.29 & 3 & 241.05 & $<0.001$ & 0.76 \\
& during the pandemic & 4526.75 & 1 & 9302.82 & $<0.001$ & 0.98 \\
\hline \multirow{2}{*}{ Gender } & before the pandemic & $<0.01$ & 1 & 684.31 & 0.951 & $<0.01$ \\
& during the pandemic & 0.57 & 1 & 1.17 & 0.280 & 0.05 \\
\hline \multirow{2}{*}{ Background } & before the pandemic & 755.97 & 1 & 684.31 & $<0.001$ & 0.75 \\
& during the pandemic & 490.40 & 1 & 1007.81 & $<0.001$ & 0.81 \\
\hline \multirow{2}{*}{ Gender $\times$} & before the pandemic & 5.661 & 1 & 5.12 & 0.025 & 0.02 \\
background & during the pandemic & 0.04 & 1 & 0.09 & 0.770 & $<0.01$ \\
\hline
\end{tabular}

A significant effect of the background was revealed. Individuals from rural areas had a stronger preference regarding contact with nature in their place of residence both before and after the pandemic. The strength of this effect is high.

Variance analysis also revealed a significant interaction effect. It turns out that the level of preference regarding contact with nature among female respondents from rural areas is higher compared to men, while the level of preference regarding contact with nature among female respondents from urban areas is lower compared to men. The strength of this effect is low and only observed during the pandemic.

Furthermore, differences in preferences regarding contact with nature depending on the distance to natural green areas have been found. The analysis showed significant differences in this variable both before and during the pandemic (Table 9). The strength of this effect is moderate.

Table 9. Differences in preferences regarding contact with nature depending on the distance from natural green spaces.

\begin{tabular}{|c|c|c|c|c|c|c|c|c|c|c|c|c|c|c|c|}
\hline \multirow{2}{*}{$\begin{array}{l}\text { Preference Regarding } \\
\text { Contact with Nature }\end{array}$} & \multicolumn{3}{|c|}{$\begin{array}{l}\geq 0.5 \mathrm{~km}(\mathrm{a}) \\
(n=19)\end{array}$} & \multicolumn{3}{|c|}{$\begin{array}{c}0.51 \div 1.0 \mathrm{~km}(\mathrm{~b}) \\
(n=99)\end{array}$} & \multicolumn{3}{|c|}{$\begin{array}{c}1.11 \div 3.0 \mathrm{~km}(\mathrm{c}) \\
(n=34)\end{array}$} & \multicolumn{3}{|c|}{$\begin{array}{c}\leq 3 \mathrm{~km}(\mathrm{~d}) \\
(n=81)\end{array}$} & \multirow{2}{*}{$H$} & \multirow{2}{*}{$p$} & \multirow{2}{*}{$\varepsilon^{2}$} \\
\hline & $\begin{array}{c}\text { Average } \\
\text { Rank }\end{array}$ & $\mathrm{Me}$ & IQR & $\begin{array}{c}\text { Average } \\
\text { Rank }\end{array}$ & $\mathrm{Me}$ & IQR & $\begin{array}{c}\text { Average } \\
\text { Rank }\end{array}$ & $\mathrm{Me}$ & IQR & $\begin{array}{c}\text { Average } \\
\text { Rank }\end{array}$ & Me & IQR & & & \\
\hline before the pandemic & 101.34 a & 3 & 3 & $115.97 \mathrm{a}, \mathrm{c}$ & 3 & 3 & $80.66_{a, d}$ & 3 & 0 & $137.19_{b}$ & 3 & 3 & 20.17 & $<0.001$ & 0.09 \\
\hline during the pandemic & $110.42_{\mathrm{a}, \mathrm{b}, \mathrm{c}}$ & 7 & 5 & $117.62_{a . b, c}$ & 7 & 3 & $86.54_{a, c}$ & 7 & 0 & $130.57_{a, b}$ & 7 & 5 & 11.06 & 0.004 & 0.05 \\
\hline
\end{tabular}

Analysis of differences in preferences regarding contact with nature as a function of distance from urban green spaces also revealed significant differences in the pre-pandemic variable (Table 10). The strength of this effect is low. 
Table 10. Differences in preferences regarding contact with nature depending on the distance from urban green spaces.

\begin{tabular}{|c|c|c|c|c|c|c|c|c|c|c|c|c|}
\hline \multirow{2}{*}{$\begin{array}{l}\text { Preference Regarding } \\
\text { Contact with Nature }\end{array}$} & \multicolumn{3}{|c|}{$\begin{array}{c}\geq 0.5 \mathrm{~km} \mathrm{(a)} \\
(n=77)\end{array}$} & \multicolumn{3}{|c|}{$\begin{array}{c}0.51 \div 1.0 \mathrm{~km}(\mathrm{~b}) \\
(n=138)\end{array}$} & \multicolumn{3}{|c|}{$\begin{array}{c}\leq 1.1 \mathrm{~km}(\mathrm{c}) \\
(n=18)\end{array}$} & \multirow{2}{*}{$H$} & \multirow{2}{*}{$p$} & \multirow{2}{*}{$\varepsilon^{2}$} \\
\hline & $\begin{array}{c}\text { Average } \\
\text { Rank }\end{array}$ & $\mathrm{Me}$ & IQR & $\begin{array}{c}\text { Average } \\
\text { Rank }\end{array}$ & $\mathrm{Me}$ & IQR & $\begin{array}{c}\text { Average } \\
\text { Rank }\end{array}$ & $\mathrm{Me}$ & IQR & & & \\
\hline before the pandemic & $114.97 \mathrm{a}, \mathrm{b}$ & 3 & 3 & $113.03_{\mathrm{a}, \mathrm{b}}$ & 3 & 3 & $156.11_{c}$ & 4.00 & 1.25 & 7.80 & 0.020 & 0.01 \\
\hline during the pandemic & 120.66 a & 7 & 4 & $110.99 \mathrm{a}$ & 7 & 3 & $147.44 \mathrm{a}$ & 9.50 & 2.25 & 5.34 & 0.069 & 0.01 \\
\hline
\end{tabular}

\section{Discussion}

The results obtained partially confirm the research hypothesis that the experience of the COVID-19 pandemic increased the need for contact with nature at one's place of residence. The analysis of answers provided by the residents indicates that, compared to the period before the pandemic, the value of natural and urban green areas, a green view outside the window, and having a private garden has increased. Having a balcony or a terrace and having one's own plot of land outside the place of residence have become less important. Nevertheless, in all surveyed categories, with the exception of the "having one's own garden" category, contact with nature was important for a minimum of $11.16 \%$ and a maximum of $54.08 \%$ of respondents.

This is consistent with a study conducted by CBOS [59] in which vast areas of greenery and open spaces around the place of residence were important for those choosing a new house or apartment (for 30\% of respondents in 2005 and for 33\% of respondents in 2010). However, it does not match the results of a study published by R. Bryk [60] just before the outbreak of the pandemic. The author examined the preferences of 130 residents of Polish cities with a population of over 500,000 who purchased an apartment between 2005 and 2018. Distance from their place of work and access to public transport was of key importance for the respondents ( $46.15 \%$ and $41.54 \%$, respectively). The proximity of green areas was mentioned by $6.92 \%$ of respondents. Only $5.77 \%$ of respondents aged between 22 and 30 were influenced in their decision by access to green areas; it was important for $8.7 \%$ of respondents aged 31-45, while for those aged between 46 and 60 the proximity of green areas was of no importance. The cited data clearly indicate a weaker need for contact with greenery than in the presented research. Differences in results may be due to the fact that respondents find it difficult to estimate the value they placed on contact with nature before the pandemic. This would imply that respondents overestimated their needs following their experience of restrictions during the pandemic. They might also suggest that these preferences are no longer as important when it comes to the purchase of a house or apartment. It would be consistent with the economic theory about making decisions in a world of limited resources and the trade-offs that this imposes.

A study by L. Anderson [61], who tested attitudes toward natural and artificial landscapes, explains why respondents placed greater value on proximity to natural rather than urban green spaces. It was proven that people valued the natural environment more highly than artificial landscapes. This was evident even at the semantic level, that is, the more the name of a given place revealed human influence on the environment, the less respondents liked it. This difference was evident even during photographic observations of unaltered areas of nature, e.g., national parks or primeval forests.

The large increase in the value placed on access to urban green spaces (from $11.16 \%$ to $55.79 \%$ ) can be explained by reflection on their function, inspired by the experience of the pandemic. Nearly $85 \%$ of the respondents admitted that, prior to the pandemic, they did not have an opinion about it. The experience of the pandemic may have led to the expansion of the previously predominant, pragmatic criteria applied to housing choices. Consistent with the findings regarding pre-pandemic preferences, the lower value attributed to urban green areas $(7.3 \%)$ is confirmed by the study carried by M. Głuszak and A. Małkowska [62] conducted in 2015-2016. When choosing accommodation, 3.0\% of the interviewed students referred to greenery around the building, while $2.7 \%$ mentioned 
the proximity of a city park. Green areas proved to be the least significant criterion in the choice of rental housing. Authors explain this mainly by pragmatic motives, taking into account students' budget constraints.

The analysis of data revealed significant differences between individuals with rural and urban backgrounds in terms of their preferences regarding contact with nature both before and during the pandemic. This effect is strong. The origin strongly affects these preferences. Respondents from rural areas had a greater preference for contact with nature in their place of residence both before and after the pandemic. We interpret the obtained effects as a strong need for contact with nature among people raised in its proximity, which does not subside once they have moved to the city. Contact with nature in the place of residence may be motivated by the appreciation of peace and quiet, attachment to the environment associated with one's place of origin, the importance of a healthy environment, the sense of freedom and space, and proximity to nature. The results would thus confirm attachment to the attributes of one's place of origin and reveal limited causal determination of development. This means that the social environment is the cause of changes in the personality of a person who is not inert to these influences [63]. This may also reveal that the rural population's decision to migrate to cities is much more often motivated not by a lack of need for contact with nature but by the social image of a poor village from which they wish to escape. Although, for a certain group of people coming from the countryside, contact with nature is a source of unpleasant feelings reminiscent of, for example, shame resulting from being a rural resident, as well as being associated with the belief of fewer opportunities to develop their skills and interests $(44 \%)$, achieve a high social position $(38 \%)$, achieve a decent standard of living (33\%), or get a good education $(31 \%)$ [64], this does not eliminate the need revealed in the results.

It is interesting to note that, prior to the pandemic, over $63 \%$ of respondents placed little or no value on having a garden. This may be linked to the assumption that it is uncommon to have one's own garden in the city; and the low probability of having one is generally accepted. A house with a garden is a typical place of residence for those living in rural areas (82\%) and small towns (25\%) [59]. The increased value placed on having a garden can be interpreted as a desire to build a sense of self-sufficiency when confronted with pandemic-related constraints [65].

Changes in housing preferences are also confirmed by numerous experts. According to the otodom.pl website, interest in ground-floor premises with gardens has grown [66]. Changes in preferences regarding the purchase of apartments with balconies [67] or houses [68] are also noticeable.

\section{Conclusions and Limitations}

The identification of residential preferences of Poles living in cities has its limitations. Some are due to the very nature of preference surveys, which are sensitive to contextual factors and, thus, subject to rapid changes. Others can be attributed to the fact that the assessment of preferences in the run-up to the pandemic was retrospective in nature. Furthermore, studies that build a picture of psychological and economic aspects of life during the pandemic are only beginning to emerge.

Any conclusions drawn must be based on logical arguments and short-term observations. Some preferences-having a balcony or a terrace and having one's own plot of land outside the city-did not change significantly. The significant main effect of one's background as well as a significant interaction effect were confirmed, revealing that the need to have contact with nature during the pandemic was greater among female respondents from rural areas.

The picture presented cannot be generalized and applied to the entire population. However, this analysis can contribute to a better understanding of certain specific aspects of the phenomenon and be useful for architectural design that takes into account social design, determining users' preferences regarding the use of designed spaces, taking into account presented trends. This is particularly true in the context of urban spaces; cities have been 
expanding on every continent, becoming living spaces and centers of professional activity for a growing number of people. The UN Department of Economic and Social Affairs predicts that by 2050 the world population will reach 9.7 billion, which is 2 billion more than today. Approx. $70 \%$ of this population will live in cities, compared to $50 \%$ today. Europe is one of the most urbanized continents, with over two-thirds of its population living in cities. Cities, therefore, play a key role in achieving the goal of sustainable development, which is essential if we are to prevent a global warming catastrophe. On the one hand, they contribute to the creation of problems; on the other hand, they solve them, thanks to their culture of innovation. In addition, through the European Green Deal, the EU has set ambitious goals to transform Europe into a climate-neutral continent by 2050. Therefore, any lessons learnt may also prove helpful in shaping the spatial development policy of cities with the aforementioned goal in mind.

Author Contributions: Conceptualization, A.S. and I.S.-M.; methodology, A.S. and I.S.-M.; software, A.S. and I.S.-M.; validation, A.S. and I.S.-M.; formal analysis, A.S. and I.S.-M.; investigation, A.S. and I.S.-M.; resources, A.S. and I.S.-M.; data curation, A.S. and I.S.-M.; writing-original draft preparation, A.S. and I.S.-M.; writing—review and editing, A.S. and I.S.-M.; visualization, A.S. and I.S.-M.; supervision, A.S. and I.S.-M.; project administration, A.S. and I.S.-M.; All authors have read and agreed to the published version of the manuscript.

Funding: This research received no external funding.

Institutional Review Board Statement: The study did not require ethical approval.

Informed Consent Statement: Informed consent was obtained from all subjects involved in the study.

Data Availability Statement: Data are included in the project carried out in 2020-2021, title: Transgressive and protective human behavior and housing preferences in the context of experiencing the COVID-19 pandemic, carried out at the Faculty of Psychology and Cognitive Science of Adam Mickiewicz University in Poznań and the Warsaw School of Economics.

Conflicts of Interest: The authors declare no conflict of interest.

\section{References}

1. Nicola, M.; Alsafi, Z.; Sohrabi, C.; Kerwan, A.; Al-Jabir, A.; Iosifidis, C.; Agha, M. The socio-economic implications of the coronavirus pandemic (COVID-19): A review. Int. J. Surg. 2020, 78, 185-193. [CrossRef] [PubMed]

2. Thanos, S.; White, M. Expectation adjustment in the housing market: Insights from the Scottish auction system. Hous. Stud. 2014, 29, 339-361. [CrossRef]

3. Kubicki, P. Odporność miast i nowe polityki miejskie. Politeja 2021, 18, 225-239. [CrossRef]

4. Available online: https://portal.umk.pl/pl/article/pamietnik-z-czasu-koronawirusa (accessed on 17 November 2021).

5. Available online: https://oees.pl/wp-content/uploads/2020/06/Ekspertyza-20.pdf (accessed on 17 November 2021).

6. Kalinowski, S.; Wyduba, W. Moja Sytuacja w Okresie Koronawirusa. Raport Końcowy z Badań, Open Eyes Economy Summit. 2021. Available online: https:/ / depot.ceon.pl/handle/123456789/20004 (accessed on 3 January 2022).

7. Męcina, J.; Potocki, P. Wpływ COVID 19 na Gospodarkę i Rynek Pracy w Polsce-Wyciagg z Raportu Badawczego. 2020. Open Eyes Economy Summit. Available online: https:/ / oees.pl/ekspertyzy / ?doing_wp_cron=1641635228.0846889019012451171875 (accessed on 3 January 2022).

8. Kalinowski, S. Od paniki do negacji: Zmiana postaw wobec COVID-19. Wieś Rol. 2020, 188, 45-65. [CrossRef]

9. NBP. Raport o Sytuacji na Rynku Nieruchomości Mieszkaniowych i Komercyjnych w Polsce w 2019 r; Departament Stabilności Finansowej: Warsaw, Poland, 2020. Available online: https://www.nbp.pl/publikacje/rynek_nieruchomosci/raport_2019.pdf (accessed on 15 March 2021).

10. Nanda, A. Residential Real Estate: Urban and Regional Economic Analysis; Routledge: Abingdon, UK; Oxford, UK; New York, NY, USA, 2019.

11. Rosen, S. Hedonic prices and implicit markets: Product differentiation in pure competition. J. Political Econ. 1974, 82, 34-55. [CrossRef]

12. Kain, J.F.; Quigley, J.M. Measuring the value of housing quality. J. Am. Stat. Assoc. 1970, 65, 532-548. [CrossRef]

13. Collen, H.; Hoekstra, J. Values as determinants of preferences for housing attributes. J. Hous. Built Environ. 2001, 16, 285-306. [CrossRef]

14. Brueckner, J.K. Lectures on Urban Economics; MIT Press: Cambridge, MA, USA, 2011.

15. Schirmer, P.M.; Van Eggermond, M.A.; Axhausen, K.W. The role of location in residential location choice models: A review of literature. J. Transp. Land Use 2014, 7, 3-21. [CrossRef] 
16. Li, J.; Ossokina, I.; Theo, A. The Empirical Estimation of Homeowners' Preferences for Green and Land-Use Characteristics: A Stated Preference Approach. In Proceedings of the 27th Annual European Real Estate Society Conference, Kaiserslautern, Germany, 2-5 June 2021. [CrossRef]

17. Stankowska, A.; Stankowska-Mazur, I. How the COVID-19 Pandemic Has Affected Residential Preferences in Poland: Analysis of Psychological and Economic Factors. Eur. Res. Stud. J. 2021, 4, 716-733. [CrossRef]

18. Hartig, T.; Lawrence, R.J. Introduction: The residential context of health. J. Soc. Issues 2003, 59, 455-473. [CrossRef]

19. Van den Berg, A.E.; Hartig, T.; Staats, H. Preference for nature in urbanized societies: Stress, restoration, and the pursuit of sustainability. J. Soc. Issues 2007, 63, 79-96. [CrossRef]

20. Junga, P.; Smolinská, R.; Krulický, T.; Machová, V. Evaluation of impact of the Covid-19 pandemic on rental housing prices in the city of Brno between 2020 and 2021. In SHS Web of Conferences; EDP Sciences: Paris, France, 2022; Volume 132. [CrossRef]

21. Tajaddini, R.; Gholipour, H.F.; Arjomandi, A. Working from home and long-term housing wealth inequality in large cities of advanced economies. Int. J. Hous. Mark. Anal. 2022. [CrossRef]

22. Rouleau, J.; Gosselin, L. Impacts of the COVID-19 lockdown on energy consumption in a Canadian social housing building. Appl. Energy 2021, 287, 116565. [CrossRef] [PubMed]

23. Liu, S.; Su, Y. The impact of the COVID-19 pandemic on the demand for density: Evidence from the U.S. housing market. Econ. Lett. 2021, 207, 110010. [CrossRef]

24. Gurney, C.M. Dangerous liaisons? Applying the social harm perspective to the social inequality, housing and health trifecta during the COVID-19 pandemic. Int. J. Hous. Policy 2021. [CrossRef]

25. Qian, X.; Qiu, S.; Zhang, G. The impact of COVID-19 on housing price: Evidence from China. Financ. Res. Lett. 2021, $43,101944$. [CrossRef]

26. Paluchowski, W.J.; Bakiera, L. (Eds.) Psychospołeczny Obraz Pierwszej Fali Pandemii COVID-19 w Polsce; Wydawnictwo Naukowe Uniwersytetu im; Adama Mickiewicza w Poznaniu: Poznań, Poland, 2020. Available online: https://covid.psych.uw.edu.pl/wpcontent/uploads/sites/50/2021/03/raporty-covid-2020.pdf (accessed on 3 January 2022).

27. Długosz, P. Trauma Pandemii COVID-19 w Polskim Społeczeństwie; CeDeWu: Warszawa, Poland, 2021.

28. Sideris, E. Człowiek w sytuacji zagrożenia COVID-19. Bezpieczeństwo. Teor. Prakt. 2021, 2, 35-51.

29. Duszyński, J.; Afelt, A.; Ochab-Marcinek, A.; Owczuk, R.; Pyrć, K.; Rosińska, M.; Rychard, A.; Smiatacz, T. Zrozumieć COVID-19. Opracowanie Zespołu ds. COVID-19 przy Prezesie Polskiej Akademii Nauk. 2020. Available online: https://informacje.pan.pl/ images/2020/opracowanie-covid19-14-09-2020/ZrozumiecCovid19_opracowanie_PAN.pdf (accessed on 3 January 2022).

30. Babicki, M.; Mastalerz-Migas, M. Występowanie zaburzeń lękowych wśród Polaków w dobie pandemii COVID-19. Psychiatr. Pol. 2020, 188, 1-13. [CrossRef]

31. Galea, S.; Merchant, R.; Lurie, N. The Mental Health Consequences of COVID-19 and Physical Distancing. JAMA Intern. Med. 2020, 180, 817-818. [CrossRef]

32. Costa, M.; Pavlo, A.; Reis, G.; Ponte, K.; Davidson, L. COVID-19 concerns among persons with mental illness. Psychiatr. Serv. 2020, 71, 1188-1190. [CrossRef]

33. Rogers, J.; Chesney, E.; Oliver, D.; Pollak, T.; McGuire, P.; Fusar-Poli, P.; Zandi, M.; Lewis, G.; David, A. Psychiatric and neuropsychiatric presentations associated with severe coronavirus infections: A systematic review and meta-analysis with comparison to the COVID-19 pandemic. Lancet Psychiatry 2020, 7, 611-627. [CrossRef]

34. Jones, A.; Grigsby-Toussaint, D.S. Housing stability and the residential context of the COVID-19 pandemic. Cities Health 2020. [CrossRef]

35. Allen-Coghlan, M.; McQuinn, K.M. The potential impact of Covid-19 on the Irish housing sector. Int. J. Hous. Mark. Anal. 2021, 5, 23. [CrossRef]

36. Ahmad, K.; Erqou, S.; Shah, M.; Nazir, U.; Morrison, A.R.; Choudhary, G.; Wu, W. Association of poor housing conditions with COVID-19 incidence and mortality across US counties. PLoS ONE 2020, 15, e0241327. [CrossRef] [PubMed]

37. Dallas, R.; Power, E. Housing policy and the COVID-19 pandemic: The importance of housing research during this health emergency. Int. J. Hous. Policy 2020, 20, 177-183. [CrossRef]

38. Amerio, A.; Brambilla, A.; Morganti, A.; Aguglia, A.; Bianchi, D.; Santi, F.; Costantini, L.; Odone, A.; Costanza, A.; Signorelli, C.; et al. COVID-19 Lockdown: Housing Built Environment's Effects on Mental Health. Int. J. Environ. Res. Public Health 2020, 17, 5973. [CrossRef] [PubMed]

39. Swiss Federal Office of Public Health (SFOPH). Plakat: Bleiben Sie jetzt zuhause. Retten Sie Leben, vom Bundesamt für Gesundheit (Version vom 20. März 2020). 2020. Available online: https://bag-coronavirus.ch/wp-content/uploads/2020/03/ BAG_StopCorona_841x1189_D.pdf (accessed on 16 March 2021).

40. Mahsa, Z.; Seyed-Abbas, Y.; Seyed-Bagher, H. COVID-19 and healthy home preferences: The case of apartment residents in Tehran. J. Build. Eng. 2021, 35, 102021.

41. Hansmann, R.; Fritz, L.; Pagani, A.; Clément, G.; Binder, C.R. Activities, housing situation, gender and further factors influencing psychological strain experienced during the first COVID-19 lockdown in Switzerland. Front. Psychol. 2021, 4300. [CrossRef]

42. Clair, A. Homes, health, and COVID-19: How poor housing adds to the hardship of the coronavirus crisis. Soc. Mark. Found. 2020. Available online: https:/ / www.smf.co.uk/commentary_podcasts/homes-health-and-covid-19-how-poor-housing-addsto-the-hardship-of-the-coronavirus-crisis / (accessed on 17 November 2021). 
43. Tinson, A.; Clair, A. Better Housing Is Crucial for Our Health and the COVID-19 Recovery. Health Found. Long Read. 2020. Available online: https:/ / www.health.org.uk/sites / default/files/2021-01/2020\%20-\%20Better\%20housing\%20is\%20crucial.pdf (accessed on 17 November 2021).

44. Bakiera, L.; Stankowska-Mazur, I.; Janowicz, K. Poczucie Sensu w Życiu Osób Dorostych Podczas Pandemii COVID-19. Obraz Pierwszej Fali Pandemii COVID-19 w Polsce; Paluchowski, W.J., Bakiera, L., Eds.; Psychospołeczny Wydawnictwo Naukowe Uniwersytetu im. Adama Mickiewicza w Poznaniu: Poznań, Poland, 2021.

45. Nanda, A.; Thanos, S.; Valtonen, E.; Xu, Y.; Zandieh, R. Forced homeward: The COVID-19 implications for housing. Town Plan. Rev. 2021, 92, 25-31. [CrossRef]

46. Pagani, A.; Fritz, L.; Hansmann, R.; Kaufmann, V.; Binder, C.R. How the first wave of COVID-19 in Switzerland affected residential preferences. Cities Health 2021. [CrossRef]

47. Bottero, M.; Bravi, M.; Caprioli, C.; Dell'Anna, F.; Dell'Ovo, M.; Oppio, A. New Housing Preferences in the COVID-19 Era: A Best-to-Worst Scaling Experiment. In Computational Science and Its Applications_ICCSA 2021; Gervasi, O., Murgante, B., Misra, S., Garau, C., Blečić, I., Taniar, D., Apduhan, B.O., Rocha, A.M.A.C., Tarantino, E., Torre, C.M., Eds.; Lecture Notes in Computer Science; Springer: Cham, Switzerland, 2021; Volume 12954.

48. Cuerdo-Vilches, T.; Navas-Martín, M.Á.; Oteiza, I. A Mixed Approach on Resilience of Spanish Dwellings and Households during COVID-19 Lockdown. Sustainability 2020, 12, 10198. [CrossRef]

49. Sanoff, H. Integrowanie Programowania, Ewaluacji i Partycypacji w Projektowaniu Architektonicznym; Podstawy teorii Z.; Stowarzyszenie Psychologia i Architektura: Poznań, Poland, 1999.

50. Gadamer, H.G. Dziedzictwo Europy; Wydawnictwo Aletheia: Warszawa, Poloand, 1992.

51. Abraham, A.; Sommerhalder, K.; Bolliger-Salzmann, H.; Abel, T. Landschaft und Gesundheit. Das Potential einer Verbindung zweier Konzepte; Institut für Sozial- und Präventivmedizin: Bern, Switzerland, 2007.

52. Kellert, S.; Wilson, E. (Eds.) The Biophilia Hypothesis; Island Press: Washington, DC, USA, 1995. [CrossRef]

53. Maas, J.; Verheij, R.A.; Vries, S.; Spreeuwenberg, P.; Schellevis, F.G.; Groenewegen, P.P. Morbidity is related to a green living environment. J. Epidemiol. Community Health 2009, 63, 967-973. [CrossRef] [PubMed]

54. Song, C.; Ikei, H.; Miyazaki, Y. Physiological Effects of Nature Therapy: A Review of the Research in Japan. Int. J. Environ. Res. Public Health 2016, 13, 781. [CrossRef] [PubMed]

55. Cackowski, J.; Nasar, J. The restorative effects of roadside vegetation-Implications for automobile driver anger and frustration Environ. Behav. 2003, 35, 736-751. [CrossRef]

56. Stankowska-Mazur, I. Psychologiczne Związki Człowieka z Naturą; Instytut Rozwoju Miast i Regionów: Warszawa, Poland; Kraków, Poland, 2020.

57. Majkut, J. O teorii i Praktyce Badań Naukowych; Wydawnictwo Adam Marszałek: Torun, Poland, 1992.

58. Sęk, M. Dobór Próby przy Pomocy Metody kuli Śniegowej (Snowball Sampling); Praktyki badawcze; Fatyga, B., Ed.; Instytut Stosowanych Nauk Społecznych UW: Warszawa, Poland, 2015.

59. Centrum Badania Opinii Publicznej. Jak Polacy Mieszkaja, a Jak Chcieliby Mieszka; Komunikat z Badań; Fundacja Centrum Badania Opinii Społecznej: Warszawa, Poland, 2010. Available online: https://www.cbos.pl/SPISKOM.POL/2010/K_120_10.PDF (accessed on 17 March 2021).

60. Bryk, R. Preferencje zakupu mieszkań w dużych miastach polski. Studia Miej. 2019, 33, 141-153. [CrossRef]

61. Anderson, L. Land use designations affect perceptions of scenic beauty in forest landscapes. For. Sci. 1981, 27, 392-400.

62. Głuszak, M.; Małkowska, A. Preferencje mieszkaniowe młodych najemców lokali mieszkalnych w Krakowie. Świat Nieruchom. 2017, 10, 39-44.

63. Kowalik, S. Rozwój Społeczny. Psychologia Rozwoju Człowieka. Rozwój Funkcji Psychicznych; Harwas-Napierała, B., Trempała, J., Eds.; Wydawnictwo Naukowe PWN: Warszawa, Poland, 2009.

64. Centrum Badania Opinii Społecznej. Wieś Polska—Stereotypy; Komunikat z Badań; Fundacja Centrum Badania Opinii Społecznej: Warszawa, Poland, 2014.

65. Centrum Badania Opinii Publicznej. Kto Marzy o Życiu na wsi, a kto o Życiu w Mieście? Komunikat z badań; Fundacja Centrum Badania Opinii Społecznej: Warszawa, Poland, 2015. Available online: https://www.cbos.pl/SPISKOM.POL/2015/K_018_15 .PDF (accessed on 17 March 2021).

66. Available online: https://inwestycje.pl/nieruchomosci/jak-zmienily-sie-preferencje-nabywcow-mieszkan/ (accessed on 17 November 2021)

67. Available online: https://www.sento.pl/poszukujemy-wiekszych-mieszkan (accessed on 17 November 2021).

68. Available online: https://www.pb.pl/dokad-zmierza-rynek-nieruchomosci-1131446 (accessed on 17 November 2021). 